http://kitaibelia.unideb.hu/

ISSN 2064-4507 (Online) • ISSN 1219-9672 (Print)

(C) 2016, Department of Botany, University of Debrecen, Hungary

21 (2): 221-226.; 2016

DOI: $10.17542 /$ kit.21.221

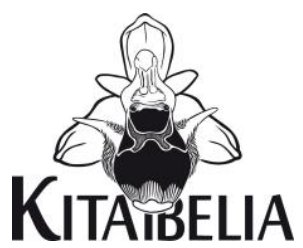

\title{
Az alacsony libatop (Chenopodium pumilio R.Br.) Zuglóban és új adatok Északkelet-Magyarország idegenhonos fajainak elterjedéséhez
}

\author{
MolnÁR Csaba \& JuHÁsz Melinda \\ H-3728 Gömörszőlős, Kassai u. 34.; birkaporkolt@yahoo.co.uk
}

The clammy goosefoot (Chenopodium pumilio R.BR.) in Zugló (Budapest) and new data on the distribution of invasive species in Northeast-Hungary

\begin{abstract}
The paper summarise occurrences of some rare invasive weeds of Hungary. We found currently second population at the Australian origin Chenopodium pumilio in Budapest (Zugló) in September 2016. Further, 27 occurrence data of 8 other species (Amaranthus deflexus, Echium maculatum, Lepidium densiflorum, Oxybaphus nyctagineus, Panicum dichotomiflorum, Portulaca grandiflora, Sarothamnus scoparius, Tragus racemosus) is also reported in the persent paper from the 'Északi-középhegyég' area (Northeast-Hungary), and some data from beside the Hungarian-Slovakian border, especially settlements, strongly disturbed places (especially road curbs, pavement cracks, train stations), indicating the Central European flora mapping system quadrate number. Voucher specimens were deposited in herbarium of Hungarian Natural History Museum, Budapest (BP).
\end{abstract}

Keywords: alien plants, biological invasion, Northeast-Hungary, railways, roadsides, weeds

Összefoglaló - A közlemény beszámol néhány Magyarországon ritkább előfordulású behurcolt gyomnövény előfordulásáról. Az ausztráliai eredetű Chenopodium pumilio második jelenleg ismert hazai állománya Budapesten (Zuglóban) került elő 2016 szeptemberében. További 8 faj (Amaranthus deflexus, Echium maculatum, Lepidium densiflorum, Oxybaphus nyctagineus, Panicum dichotomiflorum, Portulaca grandiflora, Sarothamus scoparius, Tragus racemosus) összesen 27 előfordulási adatát az Északi-középhegység területéről, különösen települések belterületéről, bolygatott élőhelyekről (útpadka, járdarepedés, vasútállomások) tesszük közzé. A bizonyítópéldányok a Magyar Természettudományi Múzeum Növénytárában (BP) kerültek elhelyezésre.

Kulcsszavak: adventív növények, behurcolt fajok, gyomok, ÉK-Magyarország, útszél, vasútvonalak

\section{Bevezetés}

Jelen közleményben néhány, Északkelet-Magyarországon ritkábban megjelenő idegenhonos növény előfordulását adjuk közre. Az adatokat települések belterületén és közvetlen környékén, erősen zavart termőhelyeken (elsősorban közutak mellett, járdarepedésekben, vasútállomásokon, esetenként erdei utak mentén és virágágyásban) gyüjtöttük. Az észlelések 2005 és 2016 között történtek, többségük 2016-ban. A fajok tudományos nevei KIRÁLY (2009) művét követik. A bizonyító herbáriumi példányok a Magyar Természettudományi Múzeum Növénytárának (BP) Carpato-Pannonicum Gyűjteményében kerültek elhelyezésre. 


\section{Alacsony libatop - Chenopodium pumilio R.Br.}

2016. szeptember 9-én, Budapesten, a XIV. kerületben, a Thököly út mentén, a Bosnyák tér és a Róna utca között (8480.4-es flóratérképezési kvadrát), az út északi oldalán, árnyas, gondozatlan virágágyásban egy különös, kis termetű libatop-félére lettünk figyelmesek. A gyűjtött példányok később a hazánkban ritka adventív Chenopodium pumilio-nak [syn. Ch. carinatum non R. Br., Dysphania pumilio (R. Br.) Mosyakin et Clemants] bizonyultak.

A fajnak Magyarországról 3 korábbi adata ismert. Először Polgár Sándor találta Győrben (PolgÁr 1925), majd Priszter Szaniszló a gárdonyi vasútállomásnál (PRISZTER 1965), végül Lengyel Attila Budán (LenGYel 2013). A két korábbi adatot azóta nem erősítették meg. Magyarország edényes növényfajainak elterjedési atlasza (BARTHA et al. 2015) ezt a 3 adatot jelöli, mivel adventív fajok esetében az atlasz nem tesz különbséget archív és recens adatok között, vagyis 2 archív és egy recens adatot mutat (Schmidt Dávid ex litt.). Az új, zuglói előfordulás, a faj második aktuális magyarországi adatának tekinthető, amely a LENGYEL (2013) által megtalált Bartók Béla utcai lelőhelytől légvonalban több mint 6 kilométer távolságra található.

Az alacsony libatop ausztráliai eredetű, mára világszerte elterjedt gyom, melynek terjedése korábban a gyapjúimporthoz (LENGYEL 2013), manapság a jármüforgalomhoz kötődik (Schmidt Dávid ex litt.). Európában már az 1800-as évek végén megjelent (ASCHERSON 1895), szórványosan néhány adata ismert Nagy-Britannia, Belgium, Svédország, Franciaország, Németország, Svájc, Ausztria, Csehország és Szlovákia területéről (AELLEN 1979), Romániából (CHYTRY 1993), Görögországból (UoTILA \& TAN 1997), Lengyelországból (Misiewicz \& KorczyŃSKi 2003), Bulgáriából (Grozeva 2007, Assyov \& Petrova 2012) és Olaszországból (CELESTI-GRAPOW et al. 2009).

\section{Karcsú-, vagy kései köles - Panicum dichotomiflorum Michx.}

2016. szeptember 17-én, a bánrévei határátkelőhely és Bánréve belterülete közötti út szélén néhány szokatlan kinézetű köles egyedet találtunk. A gyűjtött anyag később az adventív $P$. dichotomiflorum-nak bizonyult. A határozás helyességét fénykép alapján Virók Viktor is megerősítette (ex litt.). A határozáskor külön figyelmet fordítottunk arra, hogy ne tévesszük össze a hozzá nagyon hasonló Panicum schinzii Hack ex Schinz-vel, melynek megjelenése szintén várható hazánkban (MAGYAR \& KIRÁLY 2012). Az állomány hozzávetőlegesen 20-30 tőből állt és közvetlenül a mưút szegélyén, illetve a határátkelő egykori, a magyar oldalon álló építményének műút melletti padkáján nőtt.

Fontos megemlíteni, hogy Penksza Károly határozókulcsában (PEnKsza 2009) a faj leírásánál egyebek mellett jellemzőnek írja a levél érdességét, de a talált állományra ez nem jellemző, annak levelei simák. Tapasztalataim szerint pontosan ugyanilyen sima levelű a közeli Szendrő mellett élő állomány. A Flora Europaea határozókulcsa nem említi a levél érdességét vagy simaságát (CLAYTON 1980).

A karcsú köles észak-amerikai eredetű özöngyom, mely mára a Föld jelentős részén megjelent. A Flora Europaea 1980-ban még csupán Franciaország és Olaszország területéről említi, de mára Közép-Európában is elterjedt (CLAYTon 1980). Hazánkban CsiKY et al. (2004) még csak 8 kvadrátból említik, a "flóraatlasz” már 39 kvadrátból jelzi, döntően az ország nyugati és délnyugati részéből (MESTERHÁzY et al. 2015). Eddigi egyetlen északiközéphegységi adata Szendrő határából ismert, melyet Virók Viktor talált (VIRóк et al. 2004). Ma Szlovákia területén jóval kevésbé elterjedt, mint Magyarországon, kevesebb, mint tucatnyi lelőhelyről ismert, melyek közül egy Galgóc (Hlohovec) mellett, a többi mind a Kisalföldön, illetve a Bodrogközben található. Nem ismert adata a Matricum szlovákiai részéről, így Bánréve közeléből sem (FERÁKOVÁ 2002, MEDVECKÁ et al. 2012). 
Az ország délnyugati részén, mezőgazdasági területeken rövid idő alatt terhes és nehezen irtható gyomként jelent meg. Többek között széles körben elterjedt a Drávamenti- és a Pécsisíkon a kapás kultúrák és vasutak, valamint bekötőutak mentén. Kisebb mennyiségben megjelenik az említett helyek közelében lévő lápokban, mocsarakban, csatornákban, főleg az időszakosan kiszáradó mederaljakban (Csiky János ex litt., KIRÁLY et al. 2009, PINKE et al. 2016). Ugyanakkor természetes és természetközeli élőhelyek átalakításától talán nem kell tartanunk, mivel magvai csak a talaj legfelső rétegében $(2 \mathrm{~cm})$ képesek kicsírázni, és kelésének megindulása szabadföldön abban az esetben várható, ha a magvak csírázási zónájában a talaj hőmérséklete $25^{\circ} \mathrm{C}$ fölé emelkedik, vagyis nyílt felszínre van szüksége. Irtása nehéz, mert hosszan elfekvő magbankot hoz létre, kísérletek szerint a talajba temetett magvainak két év alatt mindössze 6,75 \%-a csírázott ki (MAGYAR \& HofFMANNÉ PATHY 2012).

Tövisperje - Tragus racemosus (L.) All.

A tövisperje vitatott, talán dél-afrikai eredetű gyom, mely mára az ország homokterületein jellemzően megtelepedett. Az elmúlt egy-két évtizedben vasútvonalak mentén is terjed, elsősorban a kőzúzalék peremén és a peronokon jellemző. Jó példa, hogy 2001-ben Szerencsen még biztosan nem telepedett meg (Molnár 2001), ma viszont bőven találni ott. Terméseit az utasok cipőjükön, nadrágszárukon könnyen terjesztik (KIRÁLY et al. 2009, SchмidT 2012). A Flóraatlaszban nem szereplő új adatai erről az élőhelyről [megtalálás éve, flórakvadrát száma]:

Berente és Sajószentpéter: vasútállomások [2016, 7790.3]; Dubicsány és Vadna: vasúti megállóhelyek [2016, 7789.1]; Gödöllő: vasútállomás [2006, 8482.1]; Hét: Pogonyipuszta vasúti megállóhely [2016, 7788.1]; Kazincbarcika és Sajókaza: vasútállomások [2016, 7789.2]; Miskolc: Gömöri pályaudvar [2016, 7890.4]; Sajóecseg és Sajókeresztúr: vasútállomások [2016, 7890.2]; Szerencs: vasútállomás [2016, 7893.1]; Bánréve: vasútállomás [2016, 7788.1].

Egyelőre ritkán, de megjelenik műutak szélén is: Novajidrány: Miskolc-Kassa fóút (3-as főút) mentén [2015, 7692.2]; Bánréve: Újtelep, a határátkelő felé, útszélen [2016, 7688.3]. A közelből, a 26-os és a 27-es fóút mellől jelzik VIRóK et al. (2011), a 3-as fóút bükkaljai szakasza mellől pedig SCHMotzer (2015). SCHMIDT \& KIRÁLY (2016) is jelzi, hogy vasútvonalak és gyorsforgalmú utak mentén egyaránt terjed.

A vizsgált területen már természetközeli élőhelyen is megtelepedett. Gyöngyössolymos: Kis-hegy, taposott lejtősztyeppréten [2007, 8185.4]. Hasonló élőhelyeken a Börzsönyben is ismert (NAGY 2000).

\section{Foltos kutyatej - Euphorbia maculata L.}

Észak-amerikai eredetű ruderális gyom, amely elsősorban városi jellegű környezetben, utak szélén, repedéseiben jelenik meg. Bár első adata elég régi [Szegeden gyűjtötte Lányi Béla 1906-ban (DEGEN 1907)] terjedése az utóbbi időben gyorsult fel. KIRÁLY Gergely (2009) határozója szerint nincs az Északi-középhegységben. Az első adatot innen VIRóK et al. (2004) szolgáltatják, a Jósvafő-Aggtelek vasútállomás murvás peronjáról, majd TAKÁcs et al. (2016) Hidasnémeti vasútállomásáról, a Flóraatlasz pedig már 11 kvadrátból jelzi a térségből (VojTKó et al. 2015). Új adatok: Putnok: vasútállomás és fôtér [2016, 7788.2]; Bánréve: Újtelep és a határátkelő között, útszélen [2016, 7788.1]; Kazincbarcika: Egressy Béni és Jószerencsét út mentén, járdarepedésekben [2016, 7789.2 és 7789.4]. A szomszédos szlovákiai területekről nem ismert, csak a Kisalföldről, leginkább Pozsonyból (Bratislava) van kevés számú adata (ELIÁš 2009, MEDVECKÁ et al. 2012), ami azért is figyelemre méltó, mert vannak célzott kutatások a vasútvonalak menti flóra feltárására (JeHLík et al. 2013, MÁjEKOVÁ et al. 2014). 
Vöröslő disznóparéj - Amaranthus deflexus L.

Dél-amerikai eredetű városi és ruderális gyom. Putnok: vasútállomás, járda szélén [2016, 7788.2]. Irodalmi adata a térségből Bőcsről és Szerencsről van (TAKÁcs et al. 2014).

\section{Kisvirágú csodatölcsér - Oxybaphus nyctagineus (Michx.) Sweet}

Elsősorban vasutak mentén terjeszkedő észak-amerikai gyom (pl. SoмLYAY \& LôKös 2000, KIRÁLY et al. 2009), mely megjelent a sajókeresztúri vasúti megállóhelyen is [2014, 7890.2]. Figyelemre méltó, hogy a Miskolc-Ózd vasútvonal mentén máshol eddig nem tűnt fel, pedig itt stabil állománya él. A megállóhelyen viszonylag kevés vonat áll meg.

\section{Kisvirágú zsázsa - Lepidium densiflorum Schrad.}

Észak-amerikai eredetű ruderális gyomfaj. Bánréve: vasútállomás [2016, 7788.1]; Putnok: vasútállomás [2016, 7788.2]. A térségből 2001-ben került elő először, Szendrőlád és Sajóecseg határából, vasútvonalak mellől, valamint Sajóhídvégen a Sajó homokpadjáról (VIRÓK et al. 2004), 2003-ban a sajósenyei Zsidó-rétről (FARKAS 2011), majd Bőcs és Felsőzsolca vasútállomásáról (TAKÁcs et al. 2014). Hasonló élőhelyekről közli SCHMOTZER (2015) az Egri-Bükkaljáról (Eger, Felnémet), valamint természetközelibb élőhelyeken történő megtelepedését is jelzi (Bogács, Feldebrő). Közutak, vasutak mentén terjed (Virók Viktor ex litt.).

\section{Nagyvirágú porcsin - Portulaca grandiflora Hook.}

Dél-amerikai eredetű, ritkán kivaduló kerti dísznövény. Sirok: egerbaktai műút mentén, a belterület határától távolodva követi az útszegélyt [2005, 8087.3].

\section{Seprőzanót - Sarothamnus scoparius (L.) Wimm. ex W.D.J.Koch}

Közép-Európában talán, de az Északi-középhegységben bizonyosan nem őshonos pillangós, melyet itt vadtakarmánynak ültettek, majd elvadult. Buják: a falu feletti erdők útjai mentén mindenütt [2007, 8083.3]; Szanda és Bér: Peres-hegy [2008, 8082.4]

\section{Köszönetnyilvánítás}

Köszönettel tartozunk igen hasznos lektori véleményéért Virók Viktornak és Schmidt Dávidnak, továbbá hasznos tanácsaikért Csiky Jánosnak, Lengyel Attilának és Barina Zoltánnak.

\section{Irodalom}

AEllen P. (1979): Chenopodaceae. - In: Hegi G.: Illustrierte Flora von Mitteleuropa III/2. P. Parey, Berlin \& Hamburg, pp. 533-747.

AsCherson P. (1895): Chenopodium carinatum, mit Wolle aus Australien in Mitteleuropa eingeschleppt. - Verh. Botanisher Verein Brandenburg 36: 54-55.

Assyov B. \& Petrova A. (2012): Conspectus of the Bulgarian vascular flora. - Bulgarian Biodiversity Foundation, Szófia, 492 pp.

Bartha D., Király G., Schmidt D., Tiborcz V., Barina Z., Csiky J., JakAB G., Lesku B., Schmotzer A., Vidéki R., Vojткó A. \& Zólyomi Sz. (szerk.) (2015): Magyarország edényes növényfajainak elterjedési atlasza. Nyugat-magyarországi Egyetem Kiadó, Sopron, 329 pp.

CELESTI-GRAPOW L. et al. (2009): Inventory of the non-native flora of Italy. - Plant Biosystems 143: 386-430.

Chytry M. (1993): Chenopodium pumilio R. BR., a new adventive species for Rumania. - Linzer biologische Beiträge 25 (1): 151-152. 
Clayton W.D. (1980): 132. Panicum L. - In: Tutin T.G., Heywood V.H., Burges N.A., Moore D.M., Valentine D.H., WAlters S.M. \& WebB D.A. (eds), Flora Europaea 5. Cambridge University Press, Cambridge, p. 261.

Csiky J., Király G., Oláh E., Pfeiffer N. \& Virók V. (2004): Panicum dichotomiflorum Michaux, a new element in the Hungarian flora. - Acta Botanica Hungarica 46 (1-2): 137-141.

Degen Á. (1907): Az Euphorbia maculata L. (E. thymifolia auct. europ. non Burm.) hazánknak egy új bevándorolt gyomja. - Magyar Botanikai Lapok 6: 47-50.

ELIÁš P. jun. (2009): First record of Euphorbia maculata L. (Euphorbiaceae) in Slovakia. - Thaiszia 19: 21-25.

FARKAS T. (2011): Adatok Borsod-Abaúj-Zemplén megye flórájához I. - Kitaibelia [2010] 15 (1-2): 167-179.

FERÁKovÁ V. (2002): Nové lokality zriedkavých neofytov flóry Slovenska. - Bull. Slov. Bot. Spoločn. 24: 113-116.

Grozeva N. (2007): Chenopodium pumilio (Chenopodiaceae): a new species to the Bulgarian flora. Phytologica Balcanica 13 (3): 331-334.

Jehlík V., MÁjEKov J. \& ZaliberovÁ M. (2013): New discovered adventive plants from eastern Slovakia. Thaiszia: 23: 61-66.

KIRÁLY G. (2009): Euphorbiaceae - Kutyatejfélék családja. - In: KIRÁLY G. (szerk.), Új Magyar Füvészkönyv. Magyarország hajtásos növényei. Határozókulcsok. Aggteleki Nemzeti Park Igazgatósága, Jósvafő, pp.: 268-272.

KirÁly G., BarAnyai-Nagy A., Kerekes Sz., KirÁLy A. \& Korda M. (2009): Kiegészítések a magyar adventívflóra ismeretéhez IV. - Flora Pannonica 7: 3-31.

Lengyel A. (2013): A Chenopodium pumilio R.Br. előfordulása Budán. - Kitaibelia 18 (1-2): 28-30.

Magyar L. \& Hoffmanné Pathy Zs. (2012): A kései köles (Panicum dichotomiflorum Michx.) hazai megjelenése, biológiája és a védekezés lehetőségei. - Gyomnövények, gyomirtás 12 (1): 1-20.

Magyar L. \& KiRÁLY G. (2012): Kiegészítések a Panicum (köles) nemzetség ismeretéhez - új potenciális invádorok Magyarországon. - Növényvédelem 48 (10): 457-466.

MÁjEKovÁ J., LETZ D.R., SLEZÁK M., ZaliberovÁ M. \& HrivNÁK M. (2014): Rare and threatened vascular plants of the railways in Slovakia. - Biodiversity Research and Conservation 35: 75-85.

Medvecká J., Kliment J., Májeková J., Halada L., Zaliberová M., Gojdičová E., Feráková V. \& Jarolímek I. (2012): Inventory of the alien flora of Slovakia. - Preslia 84: 257-309.

Mesterházy A., PÁl R., Király G., Sivák K., Csiky J., Kovács J.A., Tímár G., Balogh L., Schmidt D., Ódor P., Barina Z., Bauer N., Bodonczi L., Dávid J., Hudák K., Oláh E., Pfeiffer N., Purger D. Szurdoki E., VojtKó A. \& Penksza K. (2015): Panicum dichotomiflorum Michx. - In: Bartha D., KirÁly G., Schmidt D., Tiborcz V., Barina Z., Csiky J., JaKAB G., Lesku B., SchmotZer A., VidéKi R., VojtKó A. \& Zólyomi Sz. (szerk.), Magyarország edényes növényfajainak elterjedési atlasza. Nyugat-magyarországi Egyetem Kiadó, Sopron, p. 315.

MisiEWICZ J \& KoRCZyŃSKi M. (2003): Chenopodium pumilio R. Br. - an Australian species in Poland. - In: ZajĄC A., ZajĄC M. \& ZemaneK B. (eds), Phytogeographical problems of synanthropic plants. Jagellonian University, Institute of Botany, Krakkó, pp. 163-166.

Oттісн I. (2004): Der kleine Australier an der Ecke. Eine unscheinbare Pflanze erobert ihren Platz in unserer Flora. - Natur und Museum 134 (5): 149-151.

Molnár Cs. (2001): Cenchrus incertus M.A. Curtis és Tragus racemosus (L.) All. vasúti sínek mentén. Kitaibelia 6 (2): 404

NAGY J. (2000): Gyomflorisztikai adatok a Börzsöny-hegységből. - Kitaibelia 5 (1): 201-204.

Penksza K. (2009): Poaceae (Gramineae) - Pázsitfüvek családja. - In: Király G. (szerk.), Új Magyar Füvészkönyv. Magyarország hajtásos növényei. Határozókulcsok. Aggteleki Nemzeti Park Igazgatósága, Jósvafő, pp.: 498 - 540.

Pinke Gy., Blazsek K., Nagy K., Karácsony P. \& Magyar L. (2016): Néhány adventív gyomnövény előfordulása Magyarország szójavetéseiben. - In: BARina Z., BuczKó K., LôKÖs L., PAPP B., PIFKó D. \& SzURDOKI E. (szerk.), XI. Aktuális flóra- és vegetációkutatás a Kárpát-medencében. Előadások és poszterek összefoglalói. Magyar Természettudományi Múzeum, Budapest, pp. 213-214.

PolgÁR S. (1925): Neue Beiträge zur Adventivflora von Győr (Westungarn) III. - Magyar Botanikai Lapok 24: 15-23.

PRISZTER Sz. (1965): Megjegyzések adventív növényeinkhez. - Botanikai Közlemények 52: 141-152.

SCHmidT D. (2012): Bugás tövisperje (Tragus racemosus [L.] All.) - In: CsIsZÁR Á. (szerk.), Inváziós növényfajok Magyarországon. Nyugat-magyarországi Egyetem Kiadó, Sopron, pp. 334-339. 
SCHMIDT D. \& KiRÁLY G. (2016): A gyorsforgalmi úthálózat szerepe egyes növényfajok terjedésében. - In: Barina Z., Buczkó K., LőKös L., PAPP B., Pifkó D. \& Szurdoki E. (szerk.), XI. Aktuális flóra- és vegetációkutatás a Kárpát-medencében. Előadások és poszterek összefoglalói. Magyar Természettudományi Múzeum, Budapest, pp. 108-109.

Schmotzer A. (2015): Ceratocephala testiculata (Crantz) Roth és további adatok a Bükkalja flórájához. Kitaibelia 20 (1): 81-142.

SomLYAI L. \& LőKÖs L. (2000): A Polycarpon tetraphyllum L. Magyarországon, és további adatok Budapest gyomflórájához. - Kitaibelia 5 (2): 305-306.

TakÁcs A., Nagy T., SRamkó G., Lovas-Kiss Á., Süveges K., Lukács B. A., FeKETE R., LÖKi V., Malatinszky Á., E. VojtKó A., Koscsó J., Pfliegler W. P., Nótári K. \& Molnár V. A. (2016): Pótlások a Magyarország edényes növényfajainak elterjedési atlaszához I. - Kitaibelia 21 (1): 101-115.

TAKÁcs A., ZÁKÁNy A., Gulyás G., Koscsó J. \& SRAmkó G. (2014): Florisztikai adatok a Tiszántúl északi pereméről. - Kitaibelia 19 (2): 275-294.

Uotila P. \& TAn K. (1997): Chenopodium L. - In: Strid A. \& TAN K. (eds), Flora Hellenica I. Koeltz Scientific Books, Königstein, pp. 112-121.

ViróK V., FARKAS R., GulYás G. \& SRAmkó G. (2011): Florisztikai adatok Borsod-Abaúj-Zemplén megye északi részéről III. - Kitaibelia [2010] 15 (1-2): 73-84.

Virók V., FARKAS R., SzMorad F. \& BoldoghnÉ SzÚTS F. (2004): Florisztikai adatok Borsod-Abaúj-Zemplén megye északi részéről. - Kitaibelia 9 (1): 143-150.

Vojtkó A., Tóth T., Csiky J., Pintér B., Werner E., Korda M., Pifkó D., Balogh L., Barina Z., Bodonczi L., Csathó A.I., DeÁK J. Á., FARKas S., HoRváth T., Kapocsi J., KirÁly G., KovÁCS J.A., MESTERházy A., NAGY J.Gy., SChmidT D., Schmotzer A., Szalóky I., Török P., Dénes A., Házi J., Király A., Teleki B., Tiborcz V., Vidéki R., Lesku B. \& JaKAB G. (2015): Euphorbia maculata L. - In: Bartha D., Király G., Schmidt D., Tiborcz V., Barina Z., CSIKY J., JAKAв G., LeSKU B., Schmotzer A., VidÉKi R., Vojtкó A. \& Zólyomi Sz. (szerk.), Magyarország edényes növényfajainak elterjedési atlasza. Nyugat-magyarországi Egyetem Kiadó, Sopron, p. 145.

Beérkezett / received: 2016. 10. 04. Elfogadva / accepted: 2016. 10. 23. 